\title{
Don't be stupid about intelligent design
}

\begin{abstract}
President George W. Bush and Senate majority leader Bill Frist have recently publicly advocated teaching intelligent design in science classes. Their endorsement of a discredited, nonscientific view could signal a huge step backward for scientific education. It is time for educated, motivated scientists to get involved and to educate others.
\end{abstract}

In an interview with Texan reporters, Bush supported the notion of giving intelligent design equal treatment to evolution in public schools' science classes, "so people can understand what the debate is about" (1). People or children, President Bush? And is it not stated within the Constitution that we must separate church and state?

For those who have had their heads in the sand, it is worth going over the main points of intelligent design. Intelligent design challenges both Charles Darwin's theory of natural selection and other tenets of evolutionary theory by arguing that many organisms are too complex and their systems too intricate to have been accomplished through evolution alone. Unlike creationists, who eschew scientific theory and believe that God created the entire world in 6 days, design proponents accept many of the conclusions of science. They accept the cosmologists' view that the universe is 13.6 billion years old or the geologists' view that the world is 4.5 billion years old and shun the Bible's suggestion that the world is less than 10,000 years old. They accept that mutations and natural selection may have guided aspects of the natural world.

However, they say that scientists have not yet been able to explain why certain aspects of human and animal behavior have developed to be the way they are, and that our systems are simply too convoluted to have developed without a divine hand. They do not define the deity involved, other than labeling it "God," saying that intelligent design has no theology behind it - a way to avoid being called religion. They offer varied opinions on when and how God intervened: the design could have been programmed already at the time of the Big Bang, or alternatively, the designer could be continually acting throughout the course of life.

The ambiguity about when and where intelligent design occurs makes it nearly impossible to disprove - but doesn't that set a double standard? If intelligent design can't prove its existence or fill even simple holes in its theory, then why should evolution have to? Intelligent design "scientists" say that it is impossible to design and test an experiment where you can show the existence of a divine influence, but say that it is clear that God must have intervened, since there can be no other explanation.

Why should you bother with all this? Because this is not a fight for only developmental or anthropological scientists to fight. We all must be informed and we all must get involved to make sure that our lay peers know the facts. The science curriculum is being changed to incorporate intelligent design in Ohio, New Mexico, Minnesota, Kansas, and Pennsylvania - it is important to make sure this does not spread to other states, and that it is overturned in the states where it is taught. One thing is unambiguous: this sort of discussion - of religion - does not belong in the classroom.

It is hard to argue against a middle ground - a theory of life that involves the incorporation of different beliefs. Especially as at least $40 \%$ of scientists (and presumably more of the lay population) surveyed in 1997 state that they believe in God (2). A 1999 Gallup poll showed that a startling number of people (38\%) believed wholly in creationism, $43 \%$ believed in a more intelligent design-like theory, and only $18 \%$ of those surveyed believed in evolutionary theory as the sole explanation for the origin of humans. The same poll showed that increasing levels of education correlated with a belief in evolution $(65 \%$ with postgraduate degrees versus $20 \%$ with a high school degree). What exactly does this say about our schooling? That you have to have a postgraduate education to understand or believe in fact? Are Bush and Frist trying to skew these numbers even further?

As the onus is on us to make sure we are well informed, let us go over several intelligent design myths about how evolution is not able to explain our current state (summarized from the excellent ref. 3, also available online at http://www.swarthmore. edu/NatSci/cpurrin1/textbookdisclaimers/ wackononsense.pdf). Many arguments that creationists and intelligent designers use are based on misunderstandings, misconcep- tions, and miscommunications. They start by saying that evolution is only a theory, and not fact. However, the National Academy of Sciences defines a scientific theory as a "well-substantiated explanation ... that can incorporate facts, laws, inferences, and tested hypotheses" (3). And anthropologists, geologists, and biologists work every day toward filling the remaining holes in the evolutionary "theory" most of us take as fact.

Design theorists say that scientists didn't see evolution occur and can't recreate it in a dish, but this is untrue - chromosomal changes, mutations, and hybridization in plants, cells, and fruit flies have shown that changes can be seen in short order (microevolution, so to speak), and the study of fossil records over thousands of years have shown us how evolution has proceeded. They also say that mutations only eliminate traits and cannot produce new features. Those who came up with this argument have clearly never heard of a gain-of-function mutation.

An oft-cited, specious argument regards how life at the microscopic level is too intricate to have evolved. In particular, they point to the example of bacterial flagellum, with its intricate, interdependent motor proteins that couldn't possibly have formed by evolution. However, not all flagellum are complicated, and not all components are required for the appendage to work. And many of the proteins are present elsewhere in the body.

There are many other arguments and many other more comprehensive sources of material where you can learn about the ways to dismiss such arguments - check your local PBS website, the National Center for Science Education, or the National Academies of Science. But do not think this is an issue that doesn't concern you. Get informed and get involved - whether by telling your neighbors, discussing with your children, or joining action groups or committees. Thinly veiled attempts to inject religion into the classroom should be stopped by those of us with the understanding and wherewithal to do so.

\section{Ushma S. Neill Executive Editor}

1. Bumiller, E. Bush remarks roil debate over teaching evolution. New York Times. August 3, 2005, sec. A.

2. Larson, E.J., and Witham, L. 1997. Scientists are still keeping the faith. Nature. 368:435-436.

3. Rennie, J. 2002. 15 answers to creationist nonsense. Sci. Am. 287:78-85. 